\title{
Mesohabitat indicator species in a coastal stream of the Atlantic rainforest, Rio de Janeiro-Brazil
}

\author{
Carla Ferreira Rezende ${ }^{1}$, Maíra Moraes $^{2}$, Luisa Resende Manna ${ }^{2}$, Rafael Pereira Leitão ${ }^{1}$, \\ Érica Pelegrinni Caramaschi ${ }^{1} \&$ Rosana Mazzoni ${ }^{2}$ \\ 1. Laboratório de Ecologia de Peixes, Instituto de Biologia, Departamento de Ecologia, Universidade do Estado do Rio \\ de Janeiro, Av. Mal. Trompowski, s/n CCS Bloco A Ilha do Fundão; carlarezende80@gmail.com, \\ ecorafa@gmail.com,ericapc2001@yahoo.com \\ 2. Laboratório de Ecologia de Peixes, Instituto de Biologia Roberto Alcantara Gomes, Departamento de Ecologia, \\ Universidade Estadual do Rio de Janeiro, Rua São Francisco Xavier 524; guiamaira@yahoo.com.br, \\ luisamanna@gmail.com,r.mazzoni@globo.com
}

\section{Received 01-XII-2009. Corrected 10-V-2010. Accepted 15-VI-2010.}

\begin{abstract}
The Mato Grosso is a typical Atlantic Forest stream located on the East coast of Brazil, approximately $70 \mathrm{~km}$ from Rio de Janeiro city. From its source at about $800 \mathrm{~m}$ a.s.1, the stream drains a $30 \mathrm{~km}^{2}$ area of the Northwestern part of the municipality of Saquarema, state of Rio de Janeiro and flows into the Saquarema Lagoon system. We hypothesized that fish species occupy distinct mesohabitats, with the prediction that their occurrences and densities differ among the microhabitats of riffles, runs and pools. A 250m-long stretch of the stream located in its uppermost part was selected for this study, where it becomes second-order. Mesohabitat description and their fish characterization were undertaken. Fish sampling was conducted by electroshocking and after their identification and counting, they were returned to the stream. For mesohabitat characterization, a Discriminant Function Analysis (DA) was applied. The total number of samples was estimated by the Zippin method and the recorded densities were used as an Indicator Species Analysis (ISA), followed by a Monte Carlo test for 1000 permutations. The DA significantly separated the three predetermined mesohabitats (pool, riffle and run) (WL=0.13, F=187.70, $\mathrm{p}=0.001$ ). We found five species of fishes, belonging to four families and three orders. The fishes Rhamdia quelen, Phalloceros harpagos, Pimelodella lateristriga and Astyanax taeniatus are indicators of the pool environment in the Mato Grosso stream, whereas Characidium cf. vidali is an indicator of the riffle environment. The Monte Carlo test detected non-random mesohabitat use only for P. lateristriga and A. taeniatus in the pools and for Characidium cf. vidali in the riffles. We concluded that the Mato Grosso stream contains three well-defined mesohabitats, with indicator species present in two of these mesohabitats. Rev. Biol. Trop. 58 (4): 1479-1487. Epub 2010 December 01.
\end{abstract}

Key words: mesohabitat use, stream fishes, tropical stream, mesohabitat structure, habitat classification.

Rivers and streams may be regarded as hierarchical systems of patches that differ in age, size and environmental conditions. Both anthropogenic and natural processes create patchiness across a wide range of spatial scales, resulting in a complex biotope structure (Beisel et al. 1998). This environmental arrangement is a nested collection of microhabitats (i.e., ephemeral patches of uniform substratum and hydraulics) and mesohabitats (i.e., larger, more- stable channel components) which form wider and persistent units, such as sites, streams and watersheds (Frissell et al. 1986). The organization of stream fish assemblages reflects this intricate structure, because the set of biotic and abiotic features occurring in a particular moment influence the distribution, abundance and species interactions (Wootton 1998).

According to Petty \& Grossman (1996), a species' distribution is strongly influenced by 
the patch distribution of their feeding resources and therefore the insertion of biotic elements (i.e., prey abundance) should be considered in a habitat approach. Since the areas that support optimal life development and reproduction show spatio-temporal variability in their distribution, small rivers are suitable systems to test how the patchy distribution is expressed in nature (Fraser \& Sise 1980).

Streams are characterized by mosaics of mesohabitat patches, which are clearly delimited by different combinations of flow, depth and substrate composition (Angermeier \& Schlosser 1989). The most common longitudinal mesohabitats found in these systems are riffles, runs and pools (Rincón 1999). Riffles are areas of high gradient with fast-flowing, turbulent water and rocky substrates; runs are areas with relatively slower-flowing water, generally deeper than the riffles, with a smaller gradient and no turbulence; and pools are the deepest waters of all three, with a slow current and a more-homogeneous sediment (i.e., sand, clay) (Rincón 1999).

Many studies have demonstrated high specificity between fish species composition and mesohabitat - some fishes are exclusively recorded in runs or riffles, whereas others are typical inhabitants of pools (Schlosser 1982, Moyle \& Senanayake 1984, Bisson et al. 1988, Wikramanayake \& Moyle 1989, Greenberg 1991, Lobb \& Orth 1991, Pouilly 1993). These specificities can be related to a species' life history, including evolutionary and behavioral processes, physiological and morphological mechanisms (Wootton 1998).

Thus, the objective of this study was to explore mesohabitat use by fish species in a low-diversity assemblage in a typical and well-preserved stream in the Serra do Mar mountain range. We selected the Mato Grosso stream, where the fish assemblage in this site is essentially composed of five species from three orders and four families: Characiformes - Characidae Astyanax taeniatus (Jenyns 1842) and Crenuchidae Characidium cf. vidali Travassos 1967; Siluriformes - Heptapteridae, Pimelodella lateristriga (Lichtenstein 1823) and
Rhamdia quelen (Quoy \& Gaimard 1824) and Cyprinodontiformes - Poeciliidae, Phalloceros harpagos Lucinda 2008. Considering the phylogenetic distance and the evident differences in external morphology among these species, we hypothesized that they occupy (in different occurrences and densities) longitudinal mesohabitats (riffles, runs and pools).

\section{MATERIALS AND METHODS}

Study site: The Serra do Mar mountain range along the central and southern coast of Brazil contains a complex network of streams that arise in the high altitudes and flow through the Atlantic Rainforest toward the Atlantic Ocean. The Atlantic Rainforest is the secondlargest tropical rainforest in Brazil. However, this vast region has been mostly deforested and is nowadays reduced to $5 \%$ of its original distribution (Por 1992, Mazzoni \& Lobón-Cerviá 2000). It is considered one of the most important biodiversity hotspots in the world (Myers et al. 2000), with a high proportion of endemic species, many yet to be described (Böhlke et al. 1978, Abell et al. 2008). The fish fauna inhabiting the streams in this area forms an essential part of the "Southeastern Atlantic Rainforest Eco-Region", one of the 426 eco-regions of the world, according to Abell et al. (2008).

The present study was conducted in Mato Grosso stream during four months along the dry season (10 and 11 of June, 15 and 16 of July, 11 and 12 of August and 20 and 21 of September 2007), totalizing eight sampling days. The region has a humid tropical climate, with annual mean temperatures above $20^{\circ} \mathrm{C}$. The wet season occurs during spring and summer, beginning in October, with more rainfall in the summer. Mato Grosso is a typical Atlantic Forest stream of the east coast of Brazil and is located approximately $70 \mathrm{~km}$ from the city of Rio de Janeiro $\left(22^{\circ} 55^{\circ} \mathrm{S}-42^{\circ} 35^{\circ} \mathrm{W}\right)$. From its sources at about $800 \mathrm{~m}$ a.s.l, the stream drains a $30 \mathrm{~km}^{2}$ area of the northwest part of the Saquarema municipality (Rio de Janeiro) and flows into the Saquarema Lagoon system. The $250 \mathrm{~m}$ long stretch selected for this study is located 
at the uppermost areas of the stream, where the stream becomes second-order. The site has abundant riparian vegetation (i.e., closed canopy) and a substrate composed of cobble, boulder, litter, gravel, pebble and sand, along a succession of 15 mesohabitats, five of each mesohabitat (riffle, run and pool).

Mesohabitat characterization: The mesohabitats were defined visually as runs, riffles and pools. We measured the total length (m) of each mesohabitat and then marked a series of transects across the stream and $1 \mathrm{~m}$ apart. Along each transect we measured the depth $(\mathrm{cm})$, mean current velocity $(\mathrm{m} / \mathrm{s})$ and substrate type at five equidistant points (spaced according to the transect width). Each transect represented a measurement of the mesohabitat width (m). Depth measurements were taken with metric rulers and current velocity with a digital flow meter (Global Water FP101). In order to determine width, depth and area of the sampling localities we described batimetric with length and depth data. The substrate was visually categorized in five types: cobble, boulder, pebble, litter and sand. The proportional substrate cover was estimated as the proportion of points of each category in relation to all substrate measurements in each mesohabitat.
Fish sampling: We placed two blocking nets (mesh: $5 \mathrm{~mm}$ between adjacent knots) at the upstream and downstream ends of each mesohabitat. We sampled the fish by electroshocking (Mazzoni et al. 2000), until no individuals remained in the sampled portion. After sampling, the fish were identified, counted and placed in screened boxes in the stream. At the end of the sampling of the $250 \mathrm{~m}$ stretch, the fish were returned to the stream (Fig. 1).

Voucher specimens are deposited in the Ichthyological Collections of the Laboratorio de Ictiologia of the Universidade do Tocantins: Phalloceros harpagos (UNT 6771 to 6765) and the Museu Nacional do Rio de Janeiro: Astyanax taeniatus (MNRJ 29949 to 29954; 29962 to $29964 ; 29986$ to $29988 ; 29990 ; 299994$; 30000; 30003; 30005; 30006; 30011; 30016; 30018; 30027), Characidium cf. vidali (MNRJ 29955, 29959, 29967, 29969 to 29971, 29989, 29992, 29997, 30004, 30007, 30009, 30012, 30015, 30017, 30021, 30024), Pimelodella lateristriga (MNRJ 29965, 29972, 29995, 30019, 30020 , 30022) and Rhamdia quelen (MNRJ 29991).

In order to evaluate if each mesohabitat was separated as a group for the environmental variables (total length, depth and current velocity), a Discriminant Function Analysis (DA) was applied. The mesohabitats (run, riffle

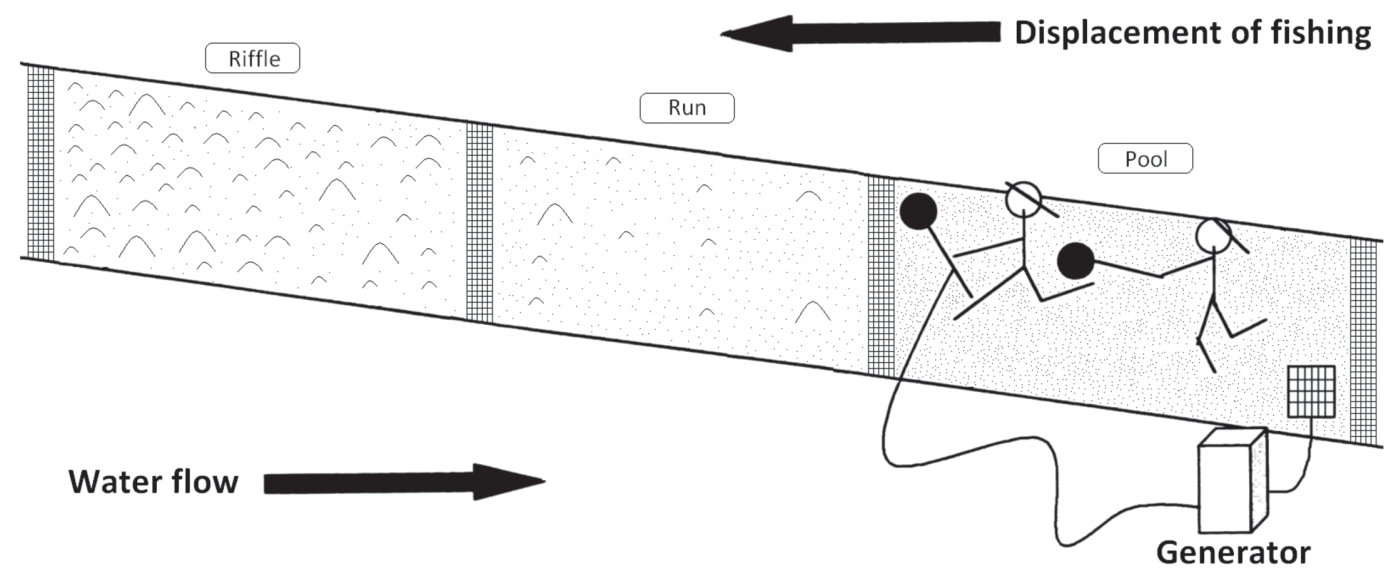

Fig. 1. Sampling procedure. The sampling site on the Mato Grosso stream was a stretch that included 15 subareas of mesohabitats, including pools, runs and riffles (Adapted from Mazzoni et al. 2000). 
and pool) were previously determined visually and then each environmental variable was measured in each mesohabitat. The variables did not satisfy the assumption of normality, so they were normalized by log-transformation $(\log x+1)$ prior to the analysis.

The total abundance of fish (number of individuals belonging to each species) was estimated by the Zippin method (1958), in which the population size can be estimated: the total number of captured fish $(\mathrm{N})$ and the estimated number of fish $(\tilde{\mathrm{N}})$, from the number of samples obtained in each successive removal. The estimated number of fish ( $\tilde{\mathrm{N}})$ per hectare (ind. ha) expressed the densities of the five fish species. The densities estimated for each species in each mesohabitat were used to apply an Indicator Species Analysis. This analysis produces an index that reaches its maximum when all individuals of a species are found in a single group of sites and when the species occurs in all sites of that group; it is a symmetrical indicator. This mesohabitats. Pools were composed by sand $(64 \%)$, litter (11\%), boulders (1\%) and cobbles (24\%). Runs were composed by sand (49\%), litter $(20 \%)$, pebbles $(6 \%)$, boulders $(1 \%)$ and cobbles (24\%). Riffles were composed by sand $(7 \%)$, litter $(1 \%)$, cobbles $(90 \%)$ and boulders (1\%). The linear environmental measurements also indicated variations between mesohabitats. Pools were wider and deeper, whereas riffles showed higher current velocities. Runs were longer and were characterized by intermediate values of width, depth and current velocity (Table 1).

The Discriminant Function Analysis corroborated the ordination of mesohabitats as a function of environmental variables, confirming the three groups considered (riffles, runs and pools). This analysis produced two axes with eigenvalues of 4.50 (first axis) and 0.35 (second axis), with an explicability of $93 \%$ and $7 \%$, respectively (Table 2 ). The DA significantly distinguished the three predetermined

TABLE 1

Minimum and maximum values of the environmental variables measured for the Mato Grosso stream mesohabitats, Saquarema

$\begin{array}{lccc} & \text { Pool }(\mathrm{N}=5) & \text { Runs }(\mathrm{N}=6) & \text { Riffles }(\mathrm{N}=6) \\ \text { Length }(\mathrm{m}) & 2.10-3.40 & 2.8-11.7 & 2.6-6.7 \\ \text { Width }(\mathrm{m}) & 0.95-3.13 & 0.7-2.7 & 0.6-1.7 \\ \text { Total Depth }(\mathrm{cm}) & 0-58 & 1-35 & 0-26.5 \\ \text { Current Velocity }(\mathrm{m} / \mathrm{s}) & 0-0.36 & 0-0.46 & 0-1.21 \\ \text { Total Area }\left(\mathrm{m}^{3}\right) & 3.71-7.95 & 9.16-18.16 & 2.7-6.05\end{array}$

index, termed the indicator value, is expressed as a percentage and range from zero (no indication) to 100 (perfect indication). The statistical significance of the species indicator values is evaluated using a randomization procedure (Monte Carlo test for 1000 permutations) (Dufrene \& Legendre 1997).

\section{RESULTS}

Mesohabitat characterization: The substrate proportions differed between
TABLE 2

Canonic classification functions and eigenvalues of the variables used to describe the three mesohabitats analyzed in the sampling area of the Mato Grosso stream, Saquarema

$\begin{array}{lcc} & \text { Factor 1 } & \text { Factor 2 } \\ \text { Length } & -6.94 & -5.23 \\ \text { Width } & 11.75 & -0.21 \\ \text { Total Depth } & -2.29 & 1.20 \\ \text { Current Velocity } & -7.66 & 13.33 \\ \text { Eigenvalues } & 4.50 & 0.35 \\ \text { Accumulated proportion } & 0.92 & 1.00\end{array}$


mesohabitats (WL=0.13, $\mathrm{F}=187.70, \mathrm{p}=0.001$ ), demonstrating a better inter-group definition (Table 3 and Fig. 2).

Indicator species: In both pool and run environments, A. taeniatus showed the highest density, respectively representing $86 \%$ and $78 \%$ of all individuals densities in these habitats. The riffle environments were dominated by Characidium cf. vidali, which represented $58 \%$ of the individual density (Table 4). Fish of all size classes were collected but most individuals were adults. Visually we did not observed spatial segregation between juveniles and adults.

Using the Indicator Species Analysis, we observed that $P$. harpagos, $P$. lateristriga, $R$.

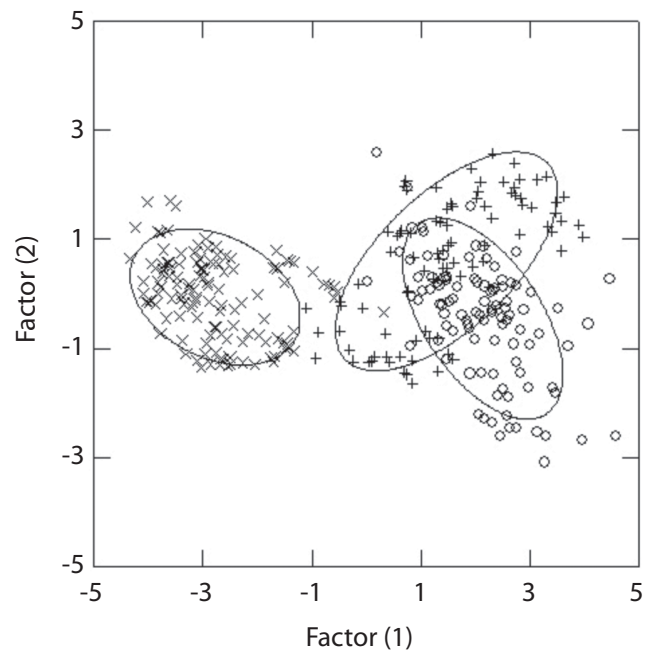

Fig. 2. Discriminant analysis, canonical scores evidencing the segregation among pool $(\mathrm{X})$, riffle $(0)$ and run $(+)$ mesohabitats.

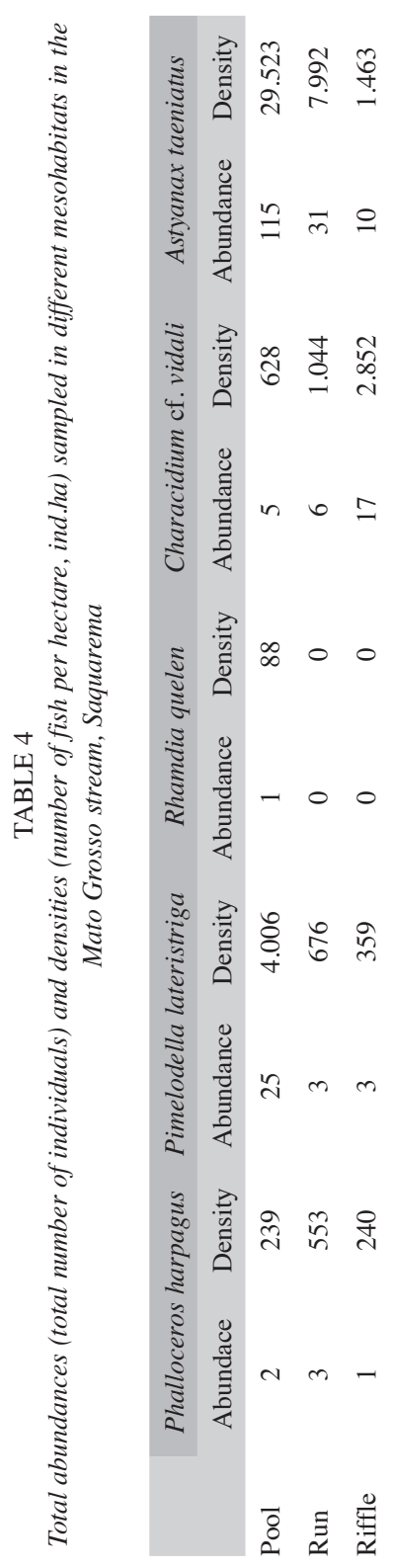

TABLE 3

Willk's Lambda generated by the Discriminant Function Analysis, demonstrating group separation and variables of the Mato Grosso stream mesohabitats, Saquarema

\begin{tabular}{|c|c|c|c|c|}
\hline & Wilks' & Partial & $\mathrm{F}$ & $\mathrm{P}$ \\
\hline Length & 0.31 & 0.42 & 288.54 & $<0.01$ \\
\hline Width & 0.24 & 0.53 & 181.30 & $<0.01$ \\
\hline Total Depth & 0.19 & 0.69 & 95.27 & $<0.01$ \\
\hline Current Velocity & 0.17 & 0.76 & 64.08 & $<0.01$ \\
\hline
\end{tabular}


TABLE 5

Monte Carlo significance test applied to the maximum value of indicator species (expressed as a percentage) for the five fish species of the Mato Grosso stream, Saquarema

$\begin{array}{lccccc} & \text { Mesohabitat } & \text { Indicator Value (\%) } & \text { Means } & \text { Standard Deviation } & \text { P } \\ \text { Phalloceros harpagos } & \text { Pool } & 20 & 27.7 & 9.63 & 0.72 \\ \text { Pimelodella lateristriga } & \text { Pool } & 81.8 & 38.2 & 12.19 & 0.004 \\ \text { Rhamdia quelen } & \text { Pool } & 16.7 & 14.9 & 1.16 & 0.28 \\ \text { Characidium cf. vidali } & \text { Riffle } & 61.6 & 38.3 & 9.56 & 0.03 \\ \text { Astyanax taeniatus } & \text { Pool } & 63.7 & 41.7 & 6.8 & 0.005\end{array}$

quelen and A.taeniatus were indicators of pool environments and that Characidium cf. vidali was a riffle indicator. The Monte Carlo test detected non-random use of the mesohabitats only for P. lateristriga and A. taeniatus in the pools and Characidium cf. vidali in the riffles (Table 5).

\section{DISCUSSION}

Three different mesohabitats were defined in the Mato Grosso stream, according to their physical characteristics: run, riffle and pool. These three units are observed in streams of different ecoregions (Hynes 1970, Rincón 1999) and are characterized by variations in current flow, depths and substrates. The presence of different mesohabitats determines a mosaic of habitats that generates higher structural complexity in the system (Angermeier \& Schlosser 1989). This complexity in stream ecosystems, especially horizontal heterogeneity and resource availability, is considered an important factor in the organization of fish communities (Gorman \& Karr 1978, Schlosser 1982, Taylor 2000). Species that preferentially inhabit riffles and runs and others that inhabit pools are widely recognized in the literature (Schlosser 1982, Moyle \& Senanayake 1984, Wikramanayake \& Moyle 1989, Greenberg 1991, Lobb \& Orth 1991, Martin-Smith 1998, Taylor 2000). Schlosser (1982) argued that species richness is higher in pool and run environments, associating this pattern with structural changes along the stream, mainly due to the deeper water in these environments. However, Greenberg (1991), analyzing benthic species densities in a temperate stream, found that more species were present in riffles and runs. This contrast can be explained by the availability of food for some benthic species that exploit resources associated with the consolidated substrates typical of riffle environments (Greenberg 1991).

In Mato Grosso stream, most species were found in the pools, corroborating by other studies (Schlosser 1982, Schlosser \& Ebel 1989, Martin-Smith 1998, Taylor 2000). This can be explained by the higher habitat complexity and/or water volume in pools (Meffe \& Berra 1988, Gorman \& Karr 1978, Martin-Smith 1998, Langeani et al. 2005). Another important factor observed in pools is the seasonal variations, which may increase species richness in this environment, where the water volume is altered and other species can arrive and occupy the pools (Langeani et al. 2005). P. harpagos, $P$. lateristriga, $R$. quelen and A.taeniatus were indicators of pool environments in the Mato Grosso stream. The association of species of these genera with pools has been noted previously. Castro \& Casatti (1997) in an Atlantic Rainforest stream in the state of São Paulo, recorded Astyanax sp., Pimelodella sp. and $R$. quelen, mainly in deep areas and pools.

Riffles are considered the least hospitable mesohabitat, because of the large amounts of energy that the fish must expend to keep themselves positioned against the current (Power 1984). This type of mesohabitat varies 
more in water volume over time and recolonization dynamics are determining factors in the structure of a riffle-associated community (Schlosser 1982). In the Mato Grosso stream, Characidium cf. vidali proved to be a riffle indicator. In another Atlantic Rainforest stream, Casatti \& Castro (1998) reported Characidium fasciatum and Characidium zebra in areas with faster current, swimming over rocky streambeds. Sabino \& Castro (1990) observed Characidium cf. vidali on rocky or sandy streambeds, in locations with moderate to strong current. Similarly, Uieda (1984) collected specimens of Characidium cf. fasciatum in areas with strong current. During underwater observations in Mato Grosso stream, we noted that Characidium cf. vidali maintains itself in the main current areas, although the fish are located in protected areas behind pebbles and boulders. This positioning may be a means of reducing energy expenditure, by keeping the fish protected from the current (R. Mazzoni, unpublished).

No species sampled in the Mato Grosso stream was an indicator of the run habitat. However, Casatti \& Castro (1998) observed a species of Astyanax using this type of habitat as a foraging area. Jowett (1993) suggested that runs are ecotones between pool and riffle environments, which would make it difficult for a specific fauna to develop there.

The mesohabitats are classified according to the structure, development, persistence and characteristics that define the existence of certain species in different types of habitat (Frissell et al. 1986). In the Mato Grosso stream, we corroborated previous studies that indicated the presence of this structural variation in these environments and the presence of indicator species observed for pools and riffles.

\section{ACKNOWLEDGMENTS}

This study is part of the $\mathrm{PhD}$ Thesis of the senior author (CFR). The sampling license was given by the Brazilian Institute of the Environment and Natural Renewable Resources - Instituto Brasileiro de Meio Ambiente (IBAMA)
(Process IBAMA/MMA 02022.002475/200610, authorization n. 118/2006 - DIFAP/ IBAMA). It was supported by FAPERJ project n. E-26/170.578/2006 and by individual grants to CFR (CNPq 140928/2005-7; CAPES-PDEE 012008-01), E.P.C (CNPq 470587/2004-0) and R.M. (CNPq 311976/2004-0). Thanks are due to the staff of the Fish Ecology Laboratory (Laboratório de Ecologia de Peixes) UERJ and UFRJ for help in the field and laboratory and to Rachel Hauser Davis for the translation of the manuscript.

\section{RESUMEN}

El estudio se realizó en el Río Mato Grosso (22 $55^{\circ}$ $\left.\mathrm{S}-42^{\circ} 35^{\circ} \mathrm{W}\right)$, donde se encontraron cinco especies de peces, pertenecientes a cuatro familias y tres órdenes. Teniendo en cuenta la distancia filogenética y la evidente diferencia morfológica externa entre ellos, nuestra hipótesis es que ellos ocupan distintos mesohabitats y que las ocurrencias y densidades difieren entre mesohabitats, previamente definidos como corriente, rápido y remanso. La colección de peces fue realizada por pesca eléctrica, los peces fueron identificados, contados y devueltos al arroyo. Para la caracterización de mesohabitats se aplicó un análisis de función discriminante (AD). El número total de ejemplares fue calculado por el método de Zippin y las densidades fueron utilizadas para un análisis de especies indicadoras (AIE), seguido de la prueba MonteCarlo para 1000 permutaciones. Los tres mesohabitats fueron separados de manera significativa por $\mathrm{AD}(\mathrm{WL}=0.13, \mathrm{~F}=187.70, \mathrm{p}=0.00)$, siendo las especies Phalloceros harpagos, Pimelodella lateristriga, Rhamdia quelen y Astyanax taeniatus indicativas del ambiente de remanso, mientras que Characidium cf. vidali del ambiente rápido. Podemos concluir que este arroyo presenta tres mesohabitats bien definidos con la presencia de especies indicadoras en estos dos mesohabitats.

Palabras clave: uso del mesohabitat, peces de arroyos, arroyo tropical, estructura del mesohabitat, clasificación del hábitat.

\section{REFERENCES}

Abell, R., M.L. Thieme, C. Revenga, M. Bryer, M. Kottelat, N. Bogutskaya, B. Coad, N. Mandrak, S.C. Balderas, W. Bussing, M.L.J. Stiassny, P. Skelton, G.R.Allen, P. Unmack, A. Naseka, R. Ng, N. Sindorf, J. Robertson, E. Armijo, J.V. Higgins, T.J. Heibel, E. Wikramanayake, D. Olson, H.L. López, R.E. Reis, J.G. Lundberg, M.H.S. Pérez \& P. Petry. 2008. Freshwater ecoregions of the world: a new map of 
biogeographic units for freshwater biodiversity conservation. BioSci. 58: 403-414.

Angermeier, P.L. \& I.J. Schlosser. 1989. Species area relationships for stream fishes. Ecol. 70: 1450-1642.

Beisel, J.N., P. Usseglio-Polatera, S. Thomas \& J.C. Moreteau. 1998. Stream community structure in relation to spatial variation: the influence of mesohabitat characteristics. Hydrobiol. 389: 73-88.

Bisson, P.A., K. Sullivan \& J.L. Nielsen. 1988. Channel hydraulics, habitat use and body form of juvenile coho salmon, steelhead and cutthroat trout in streams. Am. Fish. Soc. 117: 262-273.

Böhlke, J.E., S.H. Weitzman \& N.A. Menezes. 1978. Estado atual da sistemática dos peixes de água doce da América do Sul. Acta Amaz. 8: 657-677.

Casatti, L. \& R.M.C. Castro. 1998. A fish community of the São Francisco river headwaters riffles, southeastern Brazil. Ichthyol. Explor. Fres. 9: 229-242.

Castro, R.M.C. \& L. Casatti. 1997. The fish fauna from a small forest stream of the upper Paraná River basin, Southeastern Brasil. Ichthyol. Explor. Fres. 7: $337-$ 352 .

Dufrene, M. \& P. Legendre. 1997. Species assemblages and indicator species: the need for a flexible asymmetrical approach. Ecol. Monogra. 67: 345-366.

Fraser, D.F. \& T.E. Sise. 1980. Observation on stream minnows in a patchy environment: a test of a theory of habitat distribution. Ecol. 61: 790-797.

Frissell, C.A., W.J. Liss, C.E. Warren \& M.D. Hurley. 1986. A hierarchical framework for stream habitat classification: viewing streams in a watershed context. Environ. Manag. 10: 199-214.

Gorman, O.T. \& J.R. Karr. 1978. Habitat structure and stream fish communities. Ecol. 59: 507-515.

Greenberg, L.E. 1991. Habitat use and feeding behavior of thirteen species of benthic stream fishes. Environ. Biol. Fish. 31: 389-401.

Hynes, H.B.N. 1970. The ecology of running waters. University, Liverpool, England.
Jowett, I.G. 1993. A method for objectively identifying pool, run, and riffle habitats from physical measurements. New Zeal. J. Mar. Fresh. 27: 241-248.

Langeani, F., L. Casatti, H.S. Gameiro, A.B. Carmo \& D.C. Rossa-Feres. 2005. Riffle and pool fish communities in a large stream of southeastern Brazil. Neotrop. Ichthyol. 3: 305-311.

Lobb, M.D. \& D.J. Orth. 1991. Habitat use by an assemblage of fish in a large warm water stream. Am. Fish. Soc. 120: 65-78.

Martin-Smith, K.M. 1998. Relationships between fishes and habitat in rainforest streams in Sabah, Malaysia. J. Fish Biol. 52: 458-482.

Mazzoni, R. \& J. Lobón-Cerviá. 2000. Longitudinal structure, density and production rates of a Neotropical stream fish assemblage: the river Ubatiba in the Serra do Mar (Southeast Brazil). Ecography 23: 588-602.

Mazzoni, R., N. Fenerich-Verani \& E.P. Caramaschi. 2000. Electrofishing as a sampling technique for coastal stream fish populations and communities in the southeast of Brazil. Rev. Bras. Biol. 60: 205-216.

Meffe, G.K. \& T.M. Berra. 1988. Temporal characteristics of fish assemblage structure in an Ohio stream. Copeia 3: 684-690.

Moyle, P.B. \& F.R. Senanayake. 1984. Resource partitioning among the fishes of rainforest streams in Sri Lanka. J. Zool. 202: 195-223.

Myers, N., R.A. Mittermeier, C.G. Mittermeier, G.A.B. Fonseca \& J. Kent. 2000. Biodiversity hotspots for conservation priorities. Nature 403: 853-858.

Petty, J.T. \& G.D. Grossman. 1996. Patch selection by mottled sculpin (Pisces: Cottidae) in a southern Appalachian stream. Fresh. Biol. 35: 261-276.

Por, F.D. 1992. Sooretama. The Atlantic rain forest of Brazil. SPB Academic, The Hague, Netherlands.

Pouilly, M. 1993. Habitat ecomorphologie et structure des peuplements de poisons dans trios petit cours d'eau tropicaux de Guinée. Rev. Hydro. Trop. 26: 313-325.

Power, M.E. 1984. Depth distributions of armored catfish: predator-induced resource avoidance? Ecol. 65: 523528 . 
Rincón, P.A. 1999. Uso do micro-hábitat em peixes de riachos: métodos e perspectivas, p. 23-90. In E.P. Caramaschi, R. Mazzoni \& P.R. Peres-Neto (eds.). Ecologia de peixes de Riachos. Série Oecologia Brasiliensis, Rio de Janeiro, Brasil.

Sabino, J. \& R.M.C. Castro. 1990. Alimentação, período de atividade e distribuição espacial dos peixes de um riacho da Floresta Atlântica (Sudeste do Brasil). Rev. Bras. Biol. 50: 23-36.

Schlosser, I.J. 1982. Fish community structure and function along two habitat gradients in a headwater stream. Ecol. Monogr. 52: 395-414.

Schlosser, I.J. \& K.K. Ebel. 1989. Effects of flow regime and cyprinid predation on a headwater stream. Ecol. Monogr. 59: 41-57.
Taylor, C.M. 2000. A large-scale comparative analysis of riffle and pool fish communities in an upland stream system. Environ. Biol. Fish. 58: 89-95.

Uieda, V.S. 1984. Ocorrência e distribuição dos peixes em um riacho de água doce. Rev. Bras. Biol. 44: 203-213.

Wikramanayake, E.D. \& P.B. Moyle. 1989. Ecological structure of tropical fish assemblages in wet zone streams of Sri Lanka. J. Zool. 218: 503-526.

Wootton, R.J. 1998. Ecology of teleost fishes. Kluwer Academic, Dordrecht, Boston, USA

Zippin, C. 1958. The removal method of population estimation. J. Wildlife Manage 22: 2-90. 